\title{
Credit Guarantee and the Impact in Financial Structure of the Portuguese SMEs
}

\author{
Filipe A. P. Duarte, Luís Fernandes Rodrigues \\ Polytechnic Institute of Viseu, Viseu, Portugal \\ Maria José Madeira \\ University of Beira Interior, Covilhã, Portugal
}

\begin{abstract}
The aim of this work is to show the relevance of guarantees provided by the Mutual Credit Guarantee System (MCGS - the Portuguese Society of Credit Guarantee (SPGM)) as an instrument used in the financing of Small and Medium Enterprises (SMEs), especially in restructuring Long-Term Debt (LTD) and bank loans. The study provides empirical evidence and puts forward an explanatory model of the influence of the mutual credit guarantees on the financing of SMEs. Using data obtained from the MCGS, for the CAE (economic activity) 412 (construction of buildings, which is the sector with the greatest number of companies seeking this type of financing) and the SABI database (system for analysis of Iberian financial statements), a multiple regression model was made, studying the impact that mutual guarantees have in the financial structure of the SMEs. The results obtained show that LTD financing is positively influenced by the guarantees provided by the MCGS to SMEs as it allows greater debt capacity, especially in the medium and long term, for firms that usually cannot obtain this type of financing. The results also suggest that this type of guarantees creates an environment of confidence among all stakeholders involved, showing that both in terms of overall capital structure and in terms of merely financial credit, the response from the explanatory variables in the models was consistent with the beginning expectations, that the financial gap has been reduced with the contribution of mutual guarantees in the financing process.
\end{abstract}

Keywords: financing, credit, capital structure, mutual guarantees, SMEs and financial gap

\section{Introduction}

Small and Medium Enterprises (SMEs) need to attract and obtain external financing to ensure their financial stability and to allow their businesses to expand. This is not always possible as the various sources of external financing demand certain guarantees, particularly, for the LTD (Romano, Tanewski, \& Smyrnios,

Acknowledgements: "Este artigo é financiado por Fundos Nacionais através da FCT-Fundação para a Ciência e a Tecnologia no âmbito do projeto UID/SOC/04020/2013" (This paper is financed by National Funds provided by FCT-Foundation for Science and Technology through project UID/SOC/04020/2013).

Filipe A. P. Duarte, Ph.D., Department of Management, Administration and Tourism, School of Technology and Management of Lamego-Polytechnic Institute of Viseu, Viseu, Portugal.

Luís Fernandes Rodrigues, Ph.D., Department of Management, School of Technology and Management of Viseu—Polytechnic Institute of Viseu, Viseu, Portugal.

Maria José Madeira, Ph.D., Department of Management and Economics, University of Beira Interior, Covilhã, Portugal.

Correspondence concerning this article should be addressed to Filipe A. P. Duarte, DGAT-ESTGL, Av. Visconde Guedes Teixeira, Lamego 5100-074, Portugal. 
2001).

The fact that usually SMEs suffer from a lack of financing, particularly long term stable funds, is strongly related to information asymmetry (Gregory, Rutherford, Oswald, \& Gardiner, 2005; Berger \& Udell, 1998; Ang, 1992; Avery, Bostic, \& Samolyk, 1998). This problem, is commonly known as the financial gap (OCDE, 2005). Although SMEs are crucial in the global economy, as reflected in the OCDE (2005) report, when it was revealed that the vast majority of the total volume of worldwide business is done through SMEs, and they make up over $95 \%$ of all the companies in the world, with $99 \%$ of the world's population depending on SMEs. The OCDE (2005) gives the example that in the EU in 2003, 99.8\% of all companies were SMEs with fewer than 250 workers. In line with this research, IAPMEI - a Portuguese agency that supports SMEs and innovation, published a statistical study which revealed that in Portugal $99.9 \%$ of businesses are SMEs, and represent $77.6 \%$ of jobs (3,071 million), and produce $54.8 \%$ of the total volume of business in the country. They also state that there were 296,928 SMEs at the time (INE, 2012). Referring about data of 2015 (INE, 2015), there are $99.9 \%$ of SMEs, which represent $80.5 \%$ of jobs and produce $58.8 \%$ of the total volume of business in the country. The financial analysis of SMEs usually starts with the assumption that growth can be expected (Gregory et al., 2005; Berger \& Udell, 1998), but restrictions imposed by the market (Stiglitz \& Weiss, 1981) or credit restrictions (Storey, 1994), will condition this growth process. Furthermore, SMEs are subject to agency costs related to their financing (Ang, Cole, \& Lin, 2000), and "under-" or "over-" invest (Ang, 1992). Knill (2013) refers that in which nations find themselves, small firms play a distinctive and influential role in both the presente and future economic situations. As such, supplementary sources of financing that either directly or indirectly improve the access to finance of small listed firms are worthy of investigation. Zeitun and Tian (2007) argued that in firms, capital structure was found to have a significant and negative impact on the firm's performance measures in both the accounting and market measures that become severe financial distress problems resulting in insolvency.

For these reasons, it is a matter of great relevance that we look into the impacts of the use of collateral on company finances in Portuguese SMEs, in allowing access to credit financing.

The content of this article begins with the literature review on the subject of financing SMEs and gives an overview of the financial difficulties. After that, it presents the main variables relevant to the financing of SMEs. Section 3, describes the data and the methodology. Section 4 discusses the findings of the study showing the effect of Credit Guarantee on capital structure. In section 5 conclusions are presented.

\section{Literature Review}

SMEs are the driving force behind the world economy, not merely in terms of the numbers, but also because of the whole social and political context surrounding them. The massive instability present in the financial markets since 2007 has caused great difficulties for businesses seeking access to credit (and for individuals).

The feasibility if external financing for an SME is a subject of great significance for researchers and also of great importance for market policy all over the world. SMEs are the worst hit by the limitations they have in accessing resources, especially the lack of capital and qualified workers. There are several possible solutions for obtaining financing via banks, private lenders, public lenders, or financial institutions. 


\section{Concepts and Theoretical Context}

The main objective of the entrepreneur is to obtain the greatest possible amount of financing at the lowest cost (La Porta, Lopez-de-Silanes, Shleifer, \& Vishny, 1997). When the entrepreneur faces a situation in which he cannot raise enough funds himself to continue his project, external financing must be sought, the most common form of which, in Europe, is bank loans. This does not necessarily mean funding for the whole project is successfully found. The entrepreneur has two remaining options: he can reduce the size of his business, or find other sources of financing (Blanchflower \& Oswald, 1998; Meyer, 1990; Evans \& Jovanovic, 1989; Evans \& Leighton, 1989). Hirst, Danbolt, and Jones (2008) refer that the cost of capital is to be generally higher for companies with high levels of growth opportunities. This finding is closely linked to the lower gearing levels associated with high growth.

Jaffe and Levonian (2001) examine the relationship in 23 transition economies using cross sectional data. They find a positive and statistically significant relationship between bank sector development and economic growth.

The use of collateral is a common practice in credit contracts between businesses and lenders. The question of why the use of collateral is so widespread has been the subject of several studies. Information asymmetry is a factor which creates distance between borrowers and lenders, the existence of collateral reduces the level of risk on loans. Collateral thus has a role in supplying information to the lender about the quality of the borrower (Boot, Thakor, \& Udell, 1991; Besanko \& Thakor, 1987a, 1987b; Chan \& Kanatas, 1985; Bester, 1985), reducing credit agencies costs and preventing problems with asset substitution (Jensen \& Meckling, 1976), mitigating the problem of sub-indebtedness (Myers, 1977). Several authors (e.g. Quack \& Hildebrandt, 1995; Hutchinson, 1995; Binks, Ennewand, \& Reed, 1992) have come to refer in general to these financial restrictions - especially with regards MLT capital funding — as the financial gap. The OCDE (2005), recognised this problem as the systemic and continued discrepancy between an enterprise's financial needs and the funding made available for it to carry out its investment plans. Pan and Tian (2016) in their study, observed that family firms control entails more collateral compared with non-family firms and this difference is more pronounced when family firms face more severe conflicts of interest with banks.

Growth is a necessity for SMEs, but information asymmetry which causes the financial gap is a barrier to growth. As a consequence, given the inexistence of transparent publishing of financial information, SMEs are less likely to gain credibility with investors, banks, or other lenders. This lack of transparency (information asymmetry) means there is limited access to external funding for SMEs. From the debt viewpoint, apart from other specific external factors (Godlewiski \& Weill, 2011; Matias, 2009), the difficulty SMEs face in obtaining funding, prevents them from creating income and consequently hinders asset growth and growth potential (Degryse, Goeij, \& Kappert, 2012; Godlewiski \& Weill, 2011; Nofsinger \& Wang, 2011; Berger \& Udell, 1998; Deakins, 1996; Storey, 1994).

The fact that information asymmetry exists with SMEs, allied to poor banking records and low incentives for development, are specific reasons as to why SMEs face insufficient access to credit (Hartarska \& Gonzalez-Vega, 2006). Small companies have more opaque information than large firms, financiers have difficulty overcoming the problems of information asymmetry and in providing adequate funding for SMEs to be able to expand (Hartarska \& Gonzalez-Vega, 2006). Bass and Schrooten (2006), state that information about SMEs is rare and costly, given the return in terms of interest for credit institutions. Economic theory suggests that collateral pledges may be associated with either higher or lower risk (Berger et al., 2016). 
The Portuguese Society of Credit Guarantee (MCGS, 2016), the body that regulates the reinsurance system in Portugal, defines Credit Guarantee as a mutualist system of support for Micro and SMEs, which essentially boils down to providing financial guarantees that facilitate access to credit in conditions which are suitable for the investments and cycles of Micro and SMEs. Put simply, we might say that Credit Guarantees act as an endorsement for when a company does not have sufficient means to guarantee the credit it requests from Another Credit Institutions (ACI) or third parties (MCGS, 2016).

Although the concept is not new in financial circles, Credit Guarantees only became a fully functioning reality in Portugal in 2002, despite being created in 1998. During this time they underwent transformations and developments leading to the present day situation. The first time Portuguese State Budget (2011) clearly mentioned Credit Guarantee as a fund to which the state designates a fixed amount in 2011, and it can now be said that Portuguese state policy considers Credit Guarantee to be a helpful system of reinsurance and counter-guarantee for national SMEs. Yet for business risk and credit risk items, the highest communication is in 2009 (the year of crisis recovery). Probohudono, Tower, and Rusmin (2013) in their study argue that the increase of risk disclosure in the later years of the crisis in 2008 and 2009, has an impact in reducing estimation risk to better avoid market failure and increase market liquidity leading to more efficient capital markets.

Many questions are raised when a business seeks to expand and/or finds itself in financial difficulty. Cowan, Drexler, and Yañez (2015) show that partial credit guarantees severely affect the delinquency rate of insured loans. In particular, insured loans are $1.67 \%$ more likely to be delinquent after 24 months than similar loans without insurance. Among these is the question of financing given the restrictions on the use of its own funds. Some companies try to establish partnerships, joint-ventures, mergers, taking on new partners. But most seek third-party financing, especially from the banking sector (MCGS, 2016). Alimov (2016) highlights that firms take advantage of increased financing capacity due to collateral appreciation to gain market share at the expense of its rivals. For firms it is more likely to obtain debt from non-banking institutions or non-intermediated providers when a firm has higher risk, than from financial institutions (Aldamen, Uuncan, \& Safdar, 2012).

\section{Variables in Debt Structure}

A frequently asked question in published work on financing for businesses is about the main variables which influence debt and the value of a company (Ross, Westerfield, \& Jordan, 2008). Ross et al. (2008), have said that financial indexes are traditionally grouped in categories of short-term debtor liquidity; long-term debt or leverage; indexes for fund management necessary capital and profit indexes, or in other words, financial ratios such as solvency, financial autonomy and debt structure (ST and LTD), ROE and ROA. These ratios serve as a primary means of comparison between companies and assume that capital structure is associated to risk. That risk is often evaluated using only very scarce information.

Based on this initial analysis, a set of rations is selected which will allow to create financial indicators for the object of this study (Table 1). The use of ratios to compare companies is common practice in the published work on Corporate Finance. Ross et al. (2008), state that, while calculating indexes, it also must take into account issues such as the method of calculation.

There are in fact a substantial number of possible ratios that may be used when analysing companies. The release of indicators must take into account the purpose for which these ratios are being calculated and whether or not they are a suitable means of comparison and/or analysis for the end they hope to achieve (Ross et al., 2008). 
Using these ratios, companies are evaluated and studied, be it by banks or the MCGS responsible for Credit Guarantee, and they may be evaluated in terms of their financial solvency as well as in terms of the real and financial guarantees they offer (Table 1).

These guarantees will often allow the necessary information to be supplied, where it has often been the case that the information hitherto provided about SMEs, when compared to larger firms, has been based on too few years and incomplete (Ross et al., 2008).

Table 1

Ratios for Debt Structure

\begin{tabular}{lll}
\hline Designation & Calculation formula & Acronym \\
\hline Indebtedness ST & STD/TA & STD \\
Indebtedness LT & LTD/TA & LTD \\
Debt Structure & STD/LTD & DS \\
Financial Indebtedness ST & F STD/TA & STFC \\
Financial Indebtedness LT & F LTD/TA & LTFC \\
Financial Debt Structure & F STD/LTD & FDS \\
\hline
\end{tabular}

Notes. STD: Short-Term Debt; LTD: Long-Term Debt; TA: Total Assets; F STD: Financial Short-Term Debt; F LTD: Financial Long-Term Debt

Based on data supplied by the MCGS it is noticeable that the levels of guarantee vary considerably depending on the type of guarantee and the financial goal it refers to.

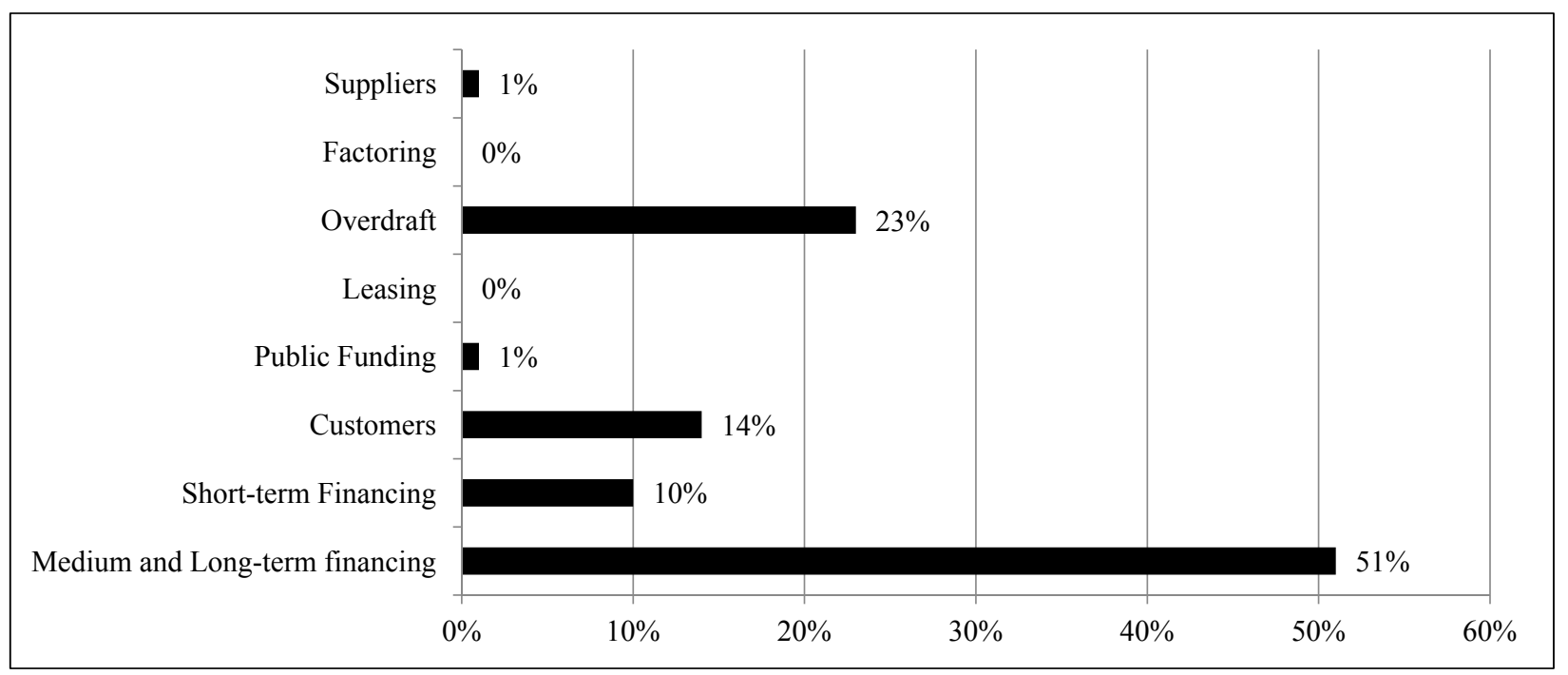

Figure 1. Structure of the total amount of guarantee given by Portuguese Mutual Credit Guarantee System to SMEs in the total sample. Source: MCGS (2003-2008).

As can be seen in Figure 1, the highest number of guarantees is for medium- and long-term financing (MLT), followed by overdraft, customers, and short-term financing, giving a total of $98 \%$, which suggests that the MCGS, above all, allows access to MLT credit, since 51\% of guarantees are for this type of financing. Guarantees for overdrafts are also high at $23 \%$. Customers at $14 \%$ and ST financing at $10 \%$ are the two items that follow. As for the remaining items, the graph shows they are relatively insignificant in percentage terms or value, although they are important for the purpose of analysis. 


\section{Research Methods}

\section{Data}

Description of the sample. The sample used for this study is based on data obtained from the MCGS, for the CAE (economic activity) 412 (construction of buildings, which is the sector with the greatest number of companies seeking this type of financing) and the SABI database (system for analysis of Iberian financial statements). Through the MCGS data were obtained for 86 Portuguese SMEs, and through SABI were obtained economic and financial data for 819 Portuguese SMEs, giving a total of 905 businesses. For the purpose of this study, it has used data for the years 2003 to 2008, allowing to obtain a total of 1,635 valid observations. In this study it is necessary and obliged to safeguard the identity of the companies, thereby it as only be used publicly available data.

Three samples were created from the available data, according to company size: small, medium and the total number of companies in the data from MCGS and SABI, based on the recommendation of the European Commission of 2003.

Big enterprises also seek access to credit, but they have other solutions available to them due largely to their size, the type of own guarantees and even their marketplace reputation. They are therefore not included in the scope of this study, because it is not expected that big enterprises show evidence of effects from this type of collateral.

After gathering and validating the data, it has been organised into three groups: small, medium, and the global sample of all businesses, which included small and medium enterprises together.

Indicators for groups of businesses that did and did not benefit from Credit Guarantee. Comparing the mean of companies that used the mutualist system with those that did not, using a descriptive analysis which allowed to compare the means of each group with a hypothesis test ( $T$-test for equal of mean) based on 8 ratios of two groups: those that use Credit Guarantee (Group 1) and those that do not use Credit Guarantee (Group 0). The ratios were chosen to compare short, medium, and long-term debt, inferring the relationship with own capital and total assets. Two types of indicators were used: those which used the total liabilities and those which used only the financial component.

In Table 2, the statistical inference shows that even when the difference of mean seems to be minimal, the $T$-test shows that the difference of mean is significant, that the mean of each group is different and has a significance level of less than 0.05 .

Thus the difference of means between groups that benefitted from Credit Guarantee and those that did not is significant, which concurs with the initial proposal. Also it must underline the fact that the number of cases studied constitutes a sufficient statistical sample.

Table 2

Summary of Descriptive Statistics

\begin{tabular}{|c|c|c|c|c|c|c|}
\hline & $N$ & Means & Standard deviation & Difference from mean & $T$-test & Sig. \\
\hline \multirow{2}{*}{ STD_T } & 1.205 & 0.544 & 0.192 & \multirow{2}{*}{0.044} & \multirow{2}{*}{4.351} & \multirow{2}{*}{0.000} \\
\hline & 430 & 0.500 & 0.173 & & & \\
\hline \multirow{2}{*}{ LTD_T } & 1.205 & 0.137 & 0.165 & \multirow{2}{*}{-0.049} & \multirow{2}{*}{-5.482} & \multirow{2}{*}{0.000} \\
\hline & 430 & 0.186 & 0.158 & & & \\
\hline \multirow{2}{*}{ DS_T } & 1.205 & 7.086 & 5.369 & \multirow{2}{*}{1.614} & \multirow{2}{*}{4.976} & \multirow{2}{*}{0.000} \\
\hline & 430 & 5.473 & 5.909 & & & \\
\hline
\end{tabular}


(Table 2 continued)

\begin{tabular}{|c|c|c|c|c|c|c|}
\hline \multirow{2}{*}{ STFC_T } & 1.205 & 3.579 & 3.601 & \multirow{2}{*}{0.469} & \multirow{2}{*}{2.371} & \multirow{2}{*}{0.018} \\
\hline & 430 & 0.109 & 0.130 & & & \\
\hline \multirow{2}{*}{$\mathrm{LTFC}_{-} \mathrm{T}$} & 1.205 & 0.136 & 0.165 & \multirow{2}{*}{0.014} & \multirow{2}{*}{1.693} & \multirow{2}{*}{0.091} \\
\hline & 430 & 0.122 & 0.138 & & & \\
\hline \multirow{2}{*}{ FDS_T } & 1.205 & 3.579 & 3.601 & \multirow{2}{*}{0.469} & \multirow{2}{*}{2.371} & \multirow{2}{*}{0.018} \\
\hline & 430 & 3.110 & 3.493 & & & \\
\hline
\end{tabular}

Notes. Total sample-These figures correspond to the data gathered and analysed in two groups: group "SABI" database with no guarantee and the group "MCGS" database with a mutual guarantee by the MCGS. To compare the means it was chosen $t$-test difference between means. For each variable, the table shows the number of observations and the figures for the following statistics: $N$ (number of valid data), mean, standard deviation, difference of mean, T-test, sig. (significance) (2003-2008). H0: The variances in both groups are equal; H1: The variances in each goup are not equal. Sample decriptions: First line represents the group SABI, the second line represents the Group MCGS, for each ratio.

\section{Purposed Model and Methodology}

\section{A model for Debt Structure With Financing Guaranteed by the MCGS}

The type of empirical evidence allows proposing explanatory models for the behaviour of enterprises in relation to debt structure.

The following explanatory multiple regression model for financing structure allows to draw conclusions about the relationship between guarantees and debt structure, especially in the LTD.

By use of the following explanatory models, the main goal is to assess the influence of guarantees in the financing structure of SMEs. With these models, it hopes to establish a causal link between the level of debt and the importance that Credit Guarantees bear on the financial ratios of Portuguese companies, thus allowing an increase in the level of debt sought or necessary for entrepreneurs to develop their businesses.

The first model will be estimated using a linear relation between the dependent variable debt structure, the ratio (DS), and the explanatory variables, as we can see in Table 3.

Table 3

Summary Statistics of the Explanatory Variables

\begin{tabular}{lllll}
\hline Variable & Average & Standard deviation & Maximum & Minimum \\
\hline TO/TA & 0.0689 & 0.5808 & 10.7716 & 0 \\
TG/TO & 0.2912 & 0.6508 & 10.7716 & 0 \\
RE/TA & 0.1516 & 0.2396 & 0.1976 & -0.2869 \\
\hline
\end{tabular}

Notes. TO/TA: Ratio of variation of the increase of Total Guarantees in relation to Total Assets (Total Operations/Total Assets); TG/TO: Ratio of solvency rating of the company (Total Guarantees/Total Operations); RE/TA: Ratio of firms historical profitability (Retained Earnings/Total Assets).

The explanatory variables are the weight of guarantees scaled by total assets, the operational coverage, and the ratio of retained earnings.

$$
\mathrm{DS}=\beta 1 \mathrm{TG} / \mathrm{TA}+\beta 2 \mathrm{TG} / \mathrm{TO}+\beta 3 \mathrm{RE} / \mathrm{TA}+\varepsilon \mathrm{i}
$$

The first variable is the weight of Total Guarantees in relation to Total Assets (TG/TA), in which the variation of the increase of Total Guarantees in relation to Total Assets is explained. This coefficient will be negative. The sign of the second variable Total Guarantees/Total Operations (TG/TO), will be positive, as the greater the weight of the guarantee in the Total Operations, the better the solvency rating of the company 
(Table 3). The third variable Retained Earnings/Total Assets (RE/TA), controls for the firms historical profitability (Pindado, Rodrigues, \& De La Torre, 2007).

Using only financial debt data, it is clear that the value of the small firms is very significant in this kind of empirical evidence, and that the bigger the firm, the less need there is for guarantees to be provided to obtain financing.

Thus, a second estimation using only financial debt to estimate the Debt Structure ratio (FDS) was built.

$$
\mathrm{FDS}=\beta 1 \mathrm{TG} / \mathrm{TA}+\beta 2 \mathrm{TG} / \mathrm{TO}+\beta 3 \mathrm{RE} / \mathrm{TA}+\varepsilon \mathrm{i}
$$

\section{Research Results}

The exploratory analysis provides empirical evidence that suggests there is a difference in the behaviour of enterprises that use the Credit Guarantee system and those that do not, in terms of their financial structuring.

\section{Results of Debt Structure Model}

Restrictions on LTD are measured not only in relation to bank loans but all liabilities. By this, it can be concluded that the use of the mutualist system contributes to the narrowing of the financial gap, allowing businesses access to MLT financing.

Table 4

Debt Structure Model

\begin{tabular}{llll}
\hline Variables & Small firms & Medium firms & All firms \\
\hline \multirow{3}{*}{$\beta 1$} & -0.449 & -1.841 & -0.632 \\
& $(0.028)^{*}$ & $(0.004)^{*}$ & $(0.001)^{*}$ \\
$\beta 2$ & -0.241 & -0.301 & -0.256 \\
& 0.521 & 0.78 & 0.669 \\
& $(0.005)^{*}$ & $(0.016)^{*}$ & $(0.000)^{*}$ \\
$\beta 3$ & 0.317 & 0.24 & 0.328 \\
& 0.615 & 3.083 & 0.798 \\
$\mathrm{R}^{2}$ & $(0.015)^{*}$ & $(0.002)^{*}$ & $(0.002)^{*}$ \\
& 0.151 & 0.319 & 0.153 \\
& 0.067 & 0.139 & $0.279^{\mathrm{a}}$ \\
\end{tabular}

Notes. Linear Regression Model based on ratios of CLT presented above in Table 2: i) *,**,*** indicate the significance level of $1 \%, 5 \%$, and $10 \%$, respectively; ii) The method for introducing data used was the enter method; iii) $\beta 1$ corresponds to the ratio TG/TA (Total Guarantees/Total Assets), $\beta 2$ corresponds to the ratio TG/TO (Total Guarantees/Total Operation), $\beta 3$ corresponds to the ratio RE/TA (Retained Earnings/Total Assets); iv) the third line for each variable contains the standardised $\beta$ 's.

For the analysis to be more accurate and more meaningful, and with a view to establishing the real impact of Credit Guarantee on capital structure, the sample was divided into three groups: one group in which small and medium enterprises are together (total), one group of small enterprises, and one group of medium enterprises. This division is based on the 2003 European commission recomendation.

In Table 4 it can be seen that the behaviour of the explanatory variables is as expected. $\beta 1$ is negative in all models, which reflects the fact that the greater the weight of the guarantees in the Total Assets, the lesser the capacity for taking on more debt in MLT. With sign of $\beta 2$ is positive, the models calculated show that the greater the weight of guarantees in the total operation, the higher the amount of financing in MLT. As for $\beta 3$, 
this reveals the positive effect of retained earnings in the granting of financing in the MLT. The results also show that the solvency in firms where MCGS had intervened was superior.

\section{Results of the Financial Debt Structure Model}

It has performed a robustness test on this result taking into account only the financial debt in this dependent variable (Table 5).

The standardised $\beta$ enables comparison to the weight of each of the variables with the explanation of the variance of the dependent variables. Thus the regressions show that for each sample, the variable that bears most influence on the model is the TG/TO, followed by TG/TA. These two variables show that the smaller a firm is, the greater its difficulty in obtaining financing, and the greater the benefits from using Credit Guarantee. By analysing the standard $\beta$ of SMEs it can be seen that the bigger a firm is, the less it needs to ask for approval for financing, as the ratio of earnings becomes the most important factor of the three under analysis (Table 5).

Table 5

Financial Debt Structure Model

\begin{tabular}{llll}
\hline \multirow{2}{*}{ Variables } & Small firms & Medium firms & All firms \\
\hline \multirow{3}{*}{$\beta 1$} & -2.897 & -0.853 & -2.052 \\
& $(0.035)^{*}$ & $(0.402)$ & $(0.034)^{*}$ \\
& -0.235 & $-0,088$ & -0.169 \\
$\beta 2$ & 3.099 & 0.506 & 2.181 \\
& $(0.013)^{*}$ & $(0.333)$ & $(0.009)^{*}$ \\
$\beta 3$ & 0.285 & 0.098 & 0.217 \\
& 2.934 & 4.429 & 3.22 \\
$\mathrm{R}^{2}$ & $(0.082)^{* *}$ & $(0.005)^{*}$ & $(0.014)^{*}$ \\
& 0.109 & 0.289 & 0.125 \\
& 0.044 & 0.092 & $0.203^{\mathrm{a}}$ \\
\hline
\end{tabular}

Notes. Linear regression model based on financial ratios of debt structure CFLT previously presented in Table 2 : i) *, **, *** indicate the significance level of $1 \%, 5 \%$, and $10 \%$, respectively; ii) the method of data introduction used was enter method; iii) $\beta 1$ corresponds to the ratio TG/TA (Total Guarantees/Total Assets), $\beta 2$ corresponds to ratio TG/TO (Total Guarantees/Total Operation), $\beta 3$ corresponds to ratio RE/TA (Retained Earnings/Total Assets); iv) the third line for each variable contains the standardised $\beta$ 's.

Table 5 shows that the behaviour of the explanatory variables is as expected. It is clear that $\beta 1$ is negative for all these samples, which shows that the greater the weight of guarantees in the Total Assets, the lesser the capacity for being granted more credit on the MLT. Conclusions for the medium firms can be concluded with the results obtained. The variables behaviour is again as expected. As for $\beta 3$, this reveals the positive effect of retained earnings in the granting of financing in the MLT.

From the analysis of standardised $\beta$ of medium and small enterprises, it can be concluded that the bigger the company, the lesser its need to seek approval for financing, as the ratio of earnings becomes the most important factor of the three under analysis. From these coefficients, it can be concluded that the variable with the lowest explanatory power in this model is the TG/TO variable, followed by TG/TA. These two variables show that the smaller a firm is, the greater its difficulty in obtaining financing, and the greater the benefits from using Credit Guarantee. 


\section{Conclusions}

Information asymmetry is one of the main obstacles standing between SMEs and stable long-term financing. This paper examined the contribution of Mutual Credit Guarantee to the reduction of the financial gap aggravated by the lack of collateral. However, there is no one general model or solution that can be applied to all SMEs to reduce the financial gap. Therefore further research is required, because SMEs are one of the great driving forces of the world economy.

There is a lack of studies, in Portugal, about this theme, mainly because the Portuguese Mutual Credit Guarantee System is still very recent. Despite this, the system is assuming a great importance, particularly to Portuguese SMEs, so deeply involved in chronic difficulties of under-financing. Recently, the Credit Guarantee System has grown immensely and the MCGS has done a great deal to develop risk-coverage instruments of this sort as mechanisms available to companies in Portugal.

The empirical evidence shows that both in terms of overall capital structure and in terms of merely financial credit, the response from the explanatory variables in the models was consistent with the beginning expectations.

Using linear regression models, it was observed that there were a significant number of firms, which have access to LTD if they have guarantees granted by the Mutual Credit Guarantee System.

The adjustment tests on the models that have been put forward and the significance levels of the explanatory variables showed the quality of the statistical inference obtained, more precisely, of the moderating effect of Credit Guarantee on information asymmetry. The use of MCGS does enable SMEs to seek LT credit more efficiently.

The evidence presented shows that Credit Guarantee has a positive influence on the capital structure of national SMEs and can be a solution to the financial gap problem.

The fact that Mutual Credit Guarantee System is part of the process of seeking credit reduces the information asymmetry between lenders and borrowers, creating a third party external evaluation of the risks involved in these operations.

This study has contributed use fully not only to raise awareness of Credit Guarantee, but also to show the influence that Mutual Credit Guarantee System can have on a company's capital structure as a stimulus for the growth and creation of SMEs in Portugal, during a period of pro-cyclical restrictions of credit.

\section{References}

Aldamen, H., Duncan, K., \& Safdar, K. (2012). Governance-default risk relationship and the demand for intermediated and non-intermediated debt. Australasian Accounting Business and Finance Journal, 6(3), 25-42.

Alimov, A. (2016). Product market effects of real estate collateral. Journal of Corporate Finance, 36, 75-92.

Ang, J. S. (1992). On the theory of finance for privately held firms. Journal of Small Business Finance, 1(3), 185-203.

Ang, J., Cole, R., \& Lin, J. (2000). Agency costs and ownership structure. Journal of Finance, 55(1), 81-106.

Avery, R. B., Bostic, R. W., \& Samolyk, K. A. (1998). The role of personal wealth in small business finance. Journal of Banking \& Finance, 22(6), 1019-1061.

Baas, T., \& Schrooten, M. (2006). Relationship banking and SMEs: A theoretical analysis. Small Business Economy, 27, 127-137.

Berger, A. N., \& Udell, G. F. (1998). The economics of small business finance: The roles of private equity and debt markets in the financial growth cycle. Journal of Banking and Finance, 22, 613-673.

Berger, A. N., Frame, W. S., \& Ioannidou, V. (2016). Reexamining the empirical relation between loan risk and collateral: The roles of collateral liquidity and types. J. Finan. Intermediation, 26, 28-46. 
Besanko, D., \& Thakor, A. (1987a). Collateral and rationing: Sorting equilibria in monopolistic and competitive credit markets. International Economic Review, 28, 671-690.

Besanko, D., \& Thakor, A. (1987b). Competitive equilibrium in the credit market under asymmetric information. Journal of Economic Theory, 42(1), 167-182.

Bester, H. (1985). Screening vs. rationing in credit markets with imperfect information. American Economic Review, 75(4), 850-855.

Binks, M., Ennewand, C., \& Reed, G. (1992). Information asymmetries and the provision of finance to small firms. International Small Business Journal, 11(1).

Blanchflower, D., \& Oswald, A. (1998). What makes an entrepreneur. Journal of Labor Economics, 16(1), 26-60.

Boot, A., Thakor, A., \& Udell, G. (1991). Secured lending and default risk: Equilibrium analysis, policy implications and empirical results. Economic Journal, 101(406), 458-472.

Chan, Y. S., \& Kanatas, G. (1985). Asymmetric valuation and the role of collateral in loan agreements. Journal of Money, Credit and Banking, 17(1), 84-95.

Cowan, K., Drexler, A., \& Yañez, A. (2015). The effect of credit guarantees on credit availability and delinquency rates. Journal of Banking \& Finance, 59, 98-110.

Deakins, D. (1996). Entrepreneurship and small firms. London: McGraw-Hill.

Degryse, H., de Goeij, P., \& Kappert, P. (2012). The impact of firm and industry characteristics on small firm's capital structure. Small Business Economics, 38(4), 431-447.

Evans, D., \& Jovanovic, B. (1989). An estimated model of entrepreneurial choice under liquidity constraints. Journal of Political Economy, 97(4), 808-827.

Evans, D., \& Leighton, L. (1989). Some empirical aspects of entrepreneurship. American Economic Review, 79(3), 519-535.

Gregory, B. T., Rutherford, M. W., Oswald, S., \& Gardiner, L. (2005). An empirical investigation of the growth cycle of small firm financing. Journal of Small Business Management, 43(4), 382-392.

Godlewiski, C., \& Weill, L. (2011). Does collateral help mitigate adverse selection? A cross country analysis. Journal of Financial Services Research, 40(1-2), 49-78.

Hartarska, V., \& Gonzalez-Vega, C. (2006). What affects new and established firms' expansion? Evidence from small firms in Russia. Small Business Economy, 27(2-3), 195-206.

Hirst, I. R. C., Danbolt, J., \& Jones, E. (2008). Required rates of return for corporate investment appraisal in the presence of growth opportunities. European Financial Management, 14(5), 989-1006.

Hutchinson, R. W. (1995). The capital structure and investment decisions of the small owner-managed firm: Some exploratory issues. Small Business Economics, 7(3), 231-239.

INE. (2012). Structural statistics of entrepreneurs. Last Accessed June 2015: (https://www.ine.pt/xportal/xmain?xpid=INE\&xpgid=ine_publicacoes\&PUBLICACOESpub_boui=210758098\&PUBLICA COEStema $=55579 \&$ PUBLICACOESmodo $=2$ )

INE. (2015). Structural statistics of entrepreneurs. Last Accessed June 2015: (https://www.ine. pt/xportal/xmain?xpid=INE\&xpgid=ine_publicacoes\&PUBLICACOESpub_boui=224784102\&PUBLICACOESmodo=2)

Jaffe, D., \& Levonian, M. (2001). The structure of banking systems in developed and transition economies. European Financial Management, 7(2), 161-181.

Jensen, M., \& Meckling, W. (1976). Theory of the firm: Managerial behavior, agency costs and ownership structure. Journal of Financial Economics, 3(4), 305-360.

Knill, A. P. (2013). Does foreign portfolio investment reach small listed firms? European Financial Management, 19(2), $251-303$.

La Porta, R., Lopez-de-Silanes, F., Shleifer, A., \& Vishny, R.W. (1997). Legal determinants of external financing. Journal of Finance, 52(3), 1131-1150.

Matias, N. M. (2009). O relacionamento bancário e o financiamento das PME. Revista Portuguese e Brasileira de Gestão. Outubro/Dezembro 2008.

MCGS. (2016). Portuguese society of credit guarantee SPGM. Last Accessed May 2016: http://www.garantiamutua.com/sistema-nacional/

Meyer, B. D. (1990). Why are there so few black entrepreneurs? NBER Working Paper 3537. Cambridge, MA.

Myers, S. C. (1977). Determinants of corporate borrowing. Journal of Financial Economics, 5(2), 147-175.

Nofsinger, R. J., \& Wang, W. (2011). Determinants of start-up firm external financing worldwide. Journal of Banking \& Finance, 35(9), 2282-2294. 
OCDE/European Communities. (2005). Oslo manual-guidelines for collecting and interpreting innovation data (3rd ed.). Paris: OECD.

Pan, X., \& Tian, G. G. (2016). Family control and loan collateral: Evidence from China. Journal of Banking \& Finance, 67, 53-68.

Pindado, J., Rodrigues, L., \& De La Torre, C. (2007). Estimating financial distress likelihood. Journal of Business Research, 61(9), 995-1003.

Portuguese State Budget. (2011). Lei n 55-A, 2010 de 31 de Dezembro; Artigo 80, ponto 4.

Probohudono, A. N., Tower, G., \& Rusmin, R. (2013). Diversity in risk communication. Australasian Accounting Business and Finance Journal, 7(1), 43-58.

Quack, S., \& Hildebrandt, S. (1995). Hausbank or fournisseur? Bank services for small and medium size enterprises in Germany and France. Wissenschaftszentrum Berlin FürSozialforschung, Discussion paper FSI-95-102.

Romano, C. A., Tanewski, G. A., \& Smyrnios, K. X. (2001). Capital structure decision making: A model for family business. Journal Business Venturing, 16(3), 285-310.

Ross, S. A., Westerfield, R. W., \& Jordan, B. D. (2008). Administraçãofinanceira. Oitava Edição: McGraw Hill.

Stiglitz, J., \& Weiss, A. (1981). Credit rationing in markets with imperfect information. American Economic Review, 71(3), 393-410.

Storey, D. (1994). Understanding the small business sector. London: Routledge.

Zeitun, R., \&Tian, G. G. (2007). Capital structure and corporate performance: Evidence from Jordan. Australasian Accounting Business and Finance Journal, 4(3), 40-61. 